\title{
Low dose linomide in Type I juvenile diabetes of recent onset: a randomised placebo-controlled double blind trial
}

\author{
R. Coutant ${ }^{1}$, P. Landais ${ }^{2}$, M. Rosilio ${ }^{1}$, C. Johnsen ${ }^{3}$, N. Lahlou ${ }^{1}$, P. Chatelain ${ }^{4}$, J. C. Carel ${ }^{1}$, J. Ludvigsson ${ }^{5}$, \\ C. Boitard ${ }^{1}$, P. F. Bougnères ${ }^{1}$ \\ ${ }^{1}$ Department of Paediatric Endocrinology, Saint-Vincent-de-Paul Hospital, Paris, France \\ ${ }^{2}$ Department of Biostatistics, Necker Hospital, Paris, France \\ ${ }^{3}$ Pharmacia, Lund, Sweden \\ ${ }^{4}$ Department of Paediatric Endocrinology, Debrousse Hospital, Lyon, France \\ ${ }^{5}$ Division of Pediatrics, University Hospital, Linköping, Sweden
}

Summary The quinoline-3-carboxamide, linomide, protects non-obese diabetic mice from diabetes. The effects of linomide on insulin needs and beta cell function were studied in recent juvenile Type I diabetes in a double-blind trial. Patients with recent onset diabetes were randomly assigned to treatment with a fixed dose of $2.5 \mathrm{mg}$ linomide (42 patients) or placebo (21 patients) for 1 year, in addition to insulin and diet. Glycated haemoglobin was $10-15 \%$ lower at 9 months $(p=0.003)$ and 12 months $(p<0.05)$ in the linomide group. The insulin dose was $32-40 \%$ smaller in the linomide group at $3(p<0.03), 6(p<0.02)$, $9(p<0.001)$ and 12 months $(p=0.01)$. Insulin doses correlated negatively with $\mathrm{C}$ peptide values $(p=0.001-0.002)$. The trend for higher $\mathrm{C}$ peptide values in the linomide group did not reach significance. In a post hoc subgroup analysis performed in 40 patients ( 25 from the linomide group and 15 from the placebo group) who still had detectable residual beta cell function at entry, linomide was associated with $45-59 \%$ higher $C$ peptide value at 6 months $(p<0.05), \quad 9$ months $\quad(p<0.05)$ and 12 months $(p<0.05)$. The main adverse effects of linomide were mild transitory anaemia (45 vs $10 \%$ in the linomide and placebo groups), thrombocytopenia (24 vs $10 \%$ ), and mild joint discomfort (45 vs $5 \%$ ) with no clinical signs. In conclusion, low-dose linomide reduced the insulin needs in patients with juvenile Type I diabetes of recent onset and improved beta cell function in patients who still had detectable beta cell function at entry. These results support further clinical and experimental studies to define the effects of linomide in Type I diabetes provided the safety of linomide is reliably established. [Diabetologia (1998) 41: 1040-1046]

Keywords Linomide, Type I diabetes.
At the end of the 1980 s, cyclosporin A and azathioprine were the first drugs reported to increase beta cell function and reduce the insulin requirements of patients with Type I diabetes of recent clinical onset. Remission in insulin dependency occurred in $40-60 \%$ of patients treated soon after diagnosis with cyclosporin A (at daily doses of $6-8 \mathrm{mg} / \mathrm{kg}$ ), but in only $20-30 \%$ of those given placebo $[1,2,3]$. Children with cyclosporin-induced remissions were able to reduce insulin injections and maintain good gly-

Received: 27 January 1998 and in revised form: 8 April 1998

Corresponding author: Pr. P.F. Bougnères, Hôpital Saint Vincent de Paul, Service d'Endocrinologie Pédiatrique, 82 avenue Denfert Rochereau, F-75014 Paris, France caemic control for a mean $\pm \mathrm{SD}$ period of $11 \pm 1$ months [4]. Three years after stopping cyclosporin, small beneficial effects were still observed in terms of $\mathrm{C}$ peptide concentrations, insulin requirements and quality of glycaemic control $[5,6]$.

While no significant adverse effect was detected in the 83 juvenile diabetic patients followed for more than 10 years in our study cohort $[5,7]$, higher doses or older age of patients, or both, were associated with renal toxicity in a meta-analysis of cyclosporin trials [7]. Azathioprine, at a daily dose of $2 \mathrm{mg} / \mathrm{kg}$, also showed positive effects, although to a lesser degree $[8,9]$. Thereafter, because of their potential toxicity and transitory effects, and despite encouraging results, the two immunosuppressive drugs did not undergo therapeutic development in Type I diabetes. 
Instead, expert committees recommended that only immunomodulating approaches should be attempted to prevent the beta cells of diabetic patients from complete destruction $[10,11]$. Since then, no new drug has shown any consistent efficacy in diabetes in humans.

We report the results of the first clinical trial of linomide in patients with Type I diabetes of recent onset. This immunomodulatory drug has shown its efficacy in experimental models of autoimmunity or cell destructive processes or both (see discussion) [12, 13]. More specifically, linomide prevents the autoimmune destruction of beta cells in diabetes-prone non-obese diabetic mice [14]. Type I diabetes of juvenile and of adult onsets differ with regard to HLA DR genotypes, the prevalence of autoimmune markers and the course of disease $[15,16]$. In the present study, we investigated the effect of low-dose linomide in juvenile patients with recent clinical onset of Type I diabetes.

\section{Subjects and methods}

Selection of patients. Eligibility criteria for inclusion in the study were age 10-20 years and definite manifestations of recent Type I diabetes [17]. Exclusion criteria were: ketoacidosis, duration of insulin therapy more than 10 days after diagnosis, non-immune mediated diabetes, risk of pregnancy, previous or current use of immunomodulatory or immunosuppressive therapy, and other serious illnesses. Altogether 63 diabetic patients (35 male and 28 female) were included in the study. Clinical characteristics of the subjects, including the 40 with detectable beta cell function at entry, are presented in Table 1.

Parents and children received detailed information about the potential side effects of linomide. They were told clearly that there was no guarantee of short, middle, or long-term medical benefit from linomide, and that the long term effects of the drug were still undefined. The therapeutic trial was approved by Cochin Institutional Review Board, and written consent was obtained from the participants and their parents.

One patient was excluded during the course of the trial after MODY3 was diagnosed in her father [18].

Insulin therapy and glycaemic control. As soon after diagnosis as possible, eligible patients were referred to the Paediatric Diabetes Unit of Saint Vincent de Paul Hospital. They were treated with three, occasionally two, daily injections of regular and longer-acting insulins and a normocaloric diet containing 45 to $50 \%$ carbohydrates. Capillary blood glucose was measured three times daily with reactive strips and reflectance metres. Children were instructed to modify their insulin doses to maintain preprandial capillary blood glucose values of between 60 and $140 \mathrm{mg} / \mathrm{dl}$ and postprandial values below $200 \mathrm{mg} / \mathrm{dl}$. Glycosylated haemoglobin was determined at entry and at 1, 3, 6, 9, 12 months (Diamat, BioRad, Richmond, Calif., USA) (normal value: $5.0 \pm 0.7 \%$, SD). Weekly phone calls to a specialised nurse and one of us (RC) allowed the insulin dose to be adjusted correctly. Insulin was actively reduced by 10-20\% when all capillary blood glucose concentrations in a one week period were less than $100 \mathrm{mg} / \mathrm{dl}$ in a patient whose monthly glycosated haemoglobin was less than $6.5 \%$. Food intake was assessed blindly by dieticians as reported [19].
Randomisation procedure. A computer generated randomisation list was supplied by Pharmacia (Uppsala, Sweden), who packed medication according to this list. All patients who fulfilled the inclusion criteria were given a treatment allocation number according to their chronological order of entry into the study (consecutive numbers were allocated and no number was avoided). Randomisation (that is, when the patient was given a specific treatment allocation number according to the randomisation list) took place the same day as the start of the study treatment. Blinding was maintained by using identical tablets of linomide and placebo, packed in glass jars with a label that had a detachable portion to be used for accountability records. Identification of treatments was possible only by opening the sealed envelopes kept by the investigator for emergency purposes.

Patients were divided into two groups, and the randomisation procedure was blocked to ensure a ratio of $2: 1$ between the linomide and the placebo group. Forty two patients (group I) were given a fixed dose of $2.5 \mathrm{mg}$ of linomide (Roquinimex, Pharmacia) once daily, and 21 patients (group II) were given placebo. The individual daily linomide dosage ranged from 0.03 to $0.09 \mathrm{mg} / \mathrm{kg}$.

At the end of study, all the envelopes were returned unopened to Pharmacia and the code was broken. Patients whose stimulated C peptide value was $\geq 0.20 \mathrm{pmol} / \mathrm{ml}$ were invited to continue with linomide treatment.

Procedural and analytical methods. Just before entry in the trial, $\mathrm{C}$ peptide tests were performed after 4-8 days of intensive insulin treatment and good metabolic control, and following $24 \mathrm{~h}$ in which the preprandial capillary blood glucose value was maintained between 60 and $140 \mathrm{mg} / \mathrm{dl}$. During the study, $\mathrm{C}$ peptide tests were performed in comparable conditions after $48 \mathrm{~h}$ of in-hospitabl normocaloric diet and glycaemic control [5]. Plasma $\mathrm{C}$ peptide concentrations were measured 0 and $6 \mathrm{~min}$ after an intravenous injection of $1 \mathrm{mg}$ of glucagon, and following an overnight fast, without prior administration of insulin. C peptide was measured with M1221 antiserum (Novo Nordisk, Bågsvaerd, Denmark). The lower limit of detection was $0.02 \mathrm{pmol} / 1$, the average precision $14 \%$ at $0.05 \mathrm{pmol} / \mathrm{ml}$ and $3 \%$ at $0.3 \mathrm{pmol} / \mathrm{ml}$.

Islet cell antibodies were measured blindly, and results were expressed by comparison with a standard reference serum [20]. Anti-GAD autoantibodies were measured using in vitro transcribed and translated recombinant human ${ }^{35} \mathrm{~S}$ GAD65 [21], and expressed as a GAD index, related to standard samples from 1996 Immunology Diabetes Workshop. Anti-IA-2 autoantibodies were measured using in vitro transcribed and translated recombinant human ${ }^{35}$ S-ICA 512/IA-2 (256-979) [22], and expressed as IA-2 index. Insulin autoantibodies were measured as reported [23].

Adverse effects. All patients were admitted to hospital at Saint Vincent de Paul at study entry, and then at 1,3, 6, 9, and 12 months. They had additional routine clinical and biological examinations at 1,2, and 3 weeks. We performed a precise clinical examination of the muscle-skeletal system, as well as measuring biological parameters of kidney, liver and gonadic functions, blood cell counts, immunoglobins, and muscle enzymes at each admission to hospital. Cardiac ultrasonography was performed every 3 months in all subjects. All events observed by the investigators (signs) or reported spontaneously by the patients (symptoms) were recorded in the case report form, with information on their seriousness, date of occurrence, duration, severity and the action taken regarding the studied drug. The description given by the investigator was converted to the classification used by the Adverse Reaction Terminology Dictionary of WHO. 
Table 1. Clinical characteristics of subjects at inclusion in the study

\begin{tabular}{|c|c|c|c|c|}
\hline & \multicolumn{2}{|l|}{ All patients } & \multicolumn{2}{|c|}{$\begin{array}{l}\text { Patients with stimulated } \\
\text { C peptide }>0.1 \mathrm{pmol} / \mathrm{ml}\end{array}$} \\
\hline & $\begin{array}{l}\text { Linomide } \\
(n=42)\end{array}$ & $\begin{array}{l}\text { Placebo } \\
(n=21)\end{array}$ & $\begin{array}{l}\text { Linomide } \\
(n=25)\end{array}$ & $\begin{array}{l}\text { Placebo } \\
(n=15)\end{array}$ \\
\hline Age (y) & $13.5 \pm 0.4$ & $12.9 \pm 0.4$ & $13.8 \pm 0.5$ & $13 \pm 0.4$ \\
\hline $\operatorname{Sex}(\mathrm{M} / \mathrm{F})$ & $26 / 16$ & $9 / 12$ & $16 / 9$ & $7 / 8$ \\
\hline Weight loss (kg) & $3.6 \pm 0.5$ & $1.9 \pm 0.5$ & $4.3 \pm 0.8$ & $1.8 \pm 0.5$ \\
\hline Weight loss as \% of body weight & $7 \pm 0.9$ & $5 \pm 1$ & $8 \pm 1$ & $4 \pm 1$ \\
\hline Duration of nycturia (days) & $41 \pm 6$ & $30 \pm 6$ & $48 \pm 9$ & $34 \pm 8$ \\
\hline Duration of insulin (days) & $6 \pm 0.5$ & $6 \pm 0.5$ & $7 \pm 1$ & $7 \pm 1$ \\
\hline Glycated haemoglobin (\%) & $13.0 \pm 0.4$ & $11.9 \pm 0.5$ & $13.1 \pm 0.5$ & $12.1 \pm 0.4$ \\
\hline Daily insulin dose (U/kg) & $1.2 \pm 0.1$ & $1.2 \pm 0.1$ & $1.1 \pm 0.1$ & $1.1 \pm 0.1$ \\
\hline \multicolumn{5}{|l|}{ C peptide (pmol/mg) } \\
\hline Fasting & $0.09 \pm 0.01$ & $0.09 \pm 0.01$ & $0.12 \pm 0.01$ & $0.11 \pm 0.01$ \\
\hline Stimulated & $0.18 \pm 0.02$ & $0.18 \pm 0.02$ & $0.26 \pm 0.02$ & $0.23 \pm 0.02$ \\
\hline Islet cell antibody (ICA) positive (\%) & $30 / 42(71)$ & $12 / 21(57)$ & $19 / 25(76)$ & $8 / 15(53)$ \\
\hline GAD positive $(\%)$ & 27/42 (64) & $14 / 21(67)$ & $15 / 25(60)$ & $9 / 15(60)$ \\
\hline IA-2 positive (\%) & $21 / 42(50)$ & $12 / 21(57)$ & $15 / 25(60)$ & $8 / 15(53)$ \\
\hline Insulin auto-antibody (IAA) positive (\%) & $9 / 42(21)$ & $8 / 21(38)$ & $6 / 25(24)$ & $5 / 15(33)$ \\
\hline ICA, GAD, IA-2, and IAA neg (\%) & $6 / 42(14)$ & 4/21 (19) & $3 / 25(12)$ & $4 / 15(27)$ \\
\hline \multicolumn{5}{|l|}{ HLA genotype } \\
\hline HLA DR3, DR4 (\%) & $12 / 42(29)$ & $7 / 21(33)$ & $8 / 25(32)$ & $5 / 15(33)$ \\
\hline HLA DR3, X (\%) & $16 / 42(38)$ & 4/21 (19) & $8 / 25(32)$ & $4 / 15(27)$ \\
\hline HLA DR4, X (\%) & $10 / 42(24)$ & $10 / 21(48)$ & $5 / 25(20)$ & $6 / 15(40)$ \\
\hline HLA not DR3, not DR4 (\%) & $4 / 42(9)$ & $0 / 21(0)$ & $4 / 25(16)$ & $0 / 15(0)$ \\
\hline
\end{tabular}

Mean values during the first week of insulin therapy

Statistics. Analysis was based on the two treatment groups. Qualitative data were compared using the chi-square test. Quantitative data were compared using the two tailed unpaired Student's $t$ test for group comparison. Repeated measures with time varying covariates were performed to explore the relation between the dose of insulin and the type of treatment as a grouping factor, the visits as within-subjects factors and glycated haemoglobin and $\mathrm{C}$ peptide as time varying covariates at times $0,1,3,6,9$, and 12 months. We considered the insulin dosages with adjustment on the glycated haemoglobin values - that is, adjustment of the glycated haemoglobin level was performed to explore whether, at a given level, the insulin doses were different in the linomide and placebo groups. We also performed a post hoc subgroup analysis by comparing linomide and placebo treatment in those patients who still had measurable residual beta cell function at entry. All values are expressed as mean \pm SEM.

\section{Results}

Whole population. The two randomised groups were comparable at diagnosis, except for a non-significant trend for duration of nycturia, glycated haemoglobin values and weight loss to be greater in the linomide group (Table 1).

Glycated haemoglobin values at 1 month remained higher $(p<0.001)$ in the linomide group as a consequence of the higher values at entry. Thereafter, glycated haemoglobin values were comparable for some time, then became lower in the linomide group at 9 months $(6.8 \pm 0.2$ vs $8.0 \pm 0.4 \%(p=0.003))$ and
12 months (7.2 plus 0.2 vs $7.9 \pm 0.3 \% \quad(p<0.05))$ (Fig. 1A).

To reach such control, linomide-treated patients required $32-40 \%$ less insulin than the control (Fig. 1B). The daily insulin doses in the treatment compared with the placebo group were $0.24 \pm 0.03$ $\mathrm{U} / \mathrm{kg}$ and $0.39 \pm 0.06 \mathrm{U} / \mathrm{kg}$ at 3 months $(p<0.03)$, $0.34 \pm 0.03 \mathrm{U} / \mathrm{kg}$ and $0.54 \pm 0.08 \mathrm{U} / \mathrm{kg}$ at 6 months $(p<0.02), 0.43 \pm 0.04 \mathrm{U} / \mathrm{kg}$ and $0.72 \pm 0.08 \mathrm{U} / \mathrm{kg}$ at 9 months $(p<0.001)$ and $0.54 \pm 0.05 \mathrm{U} / \mathrm{kg}$ and $0.77 \pm 0.05 \mathrm{U} / \mathrm{kg}$ at 12 months $(p<0.01)$. The effects of treatment with linomide compared with placebo on insulin doses were found to be significant $(p=0.01)$ by repeated measures with glycated haemoglobin as a time-varying covariate. In summary, the insulin doses of the linomide-treated patients, whose mean glycated haemoglobin value was lower, were only $60 \%$ of those of the control group from 6 to 12 months. Patients were encouraged to maintain insulin injections even at minimal dosages, and therefore none stopped injecting.

Differences in plasma C peptide concentrations, despite a consistent trend towards slightly higher values in linomide-treated patients, did not reach significance (Fig. 1C). Patients treated with linomide had an increased ratio of stimulated serum $\mathrm{C}$ peptide to glucose between months 6 and 12 of the trial $(p<0.05)$. At months 3, 6, 9 and 12 of the trial, $C$ peptide values correlated negatively with insulin doses, with correlation coefficients ranging from 0.46 to 0.54 $(p=0.002-0.001)$. 


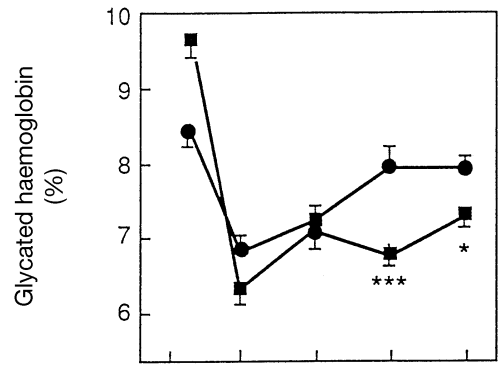

A

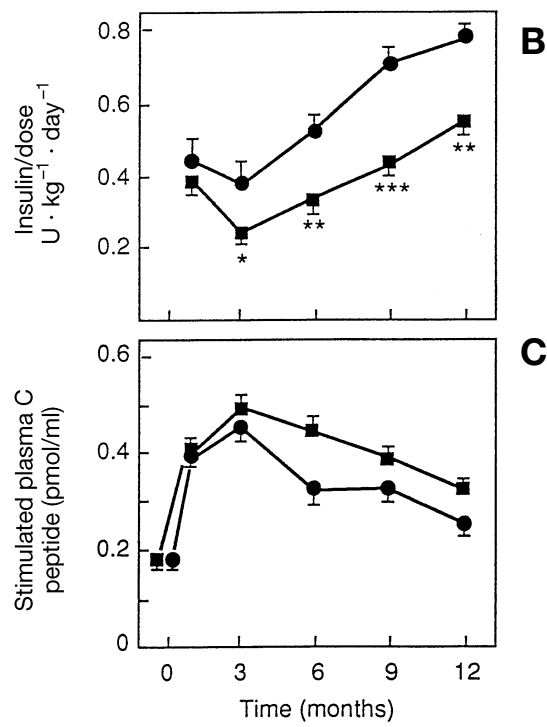

Fig.1A-C. Evolution of glycated haemoglobin (A), insulin dose (B) and glucagon-stimulated plasma $\mathbf{C}$ peptide $(\mathbf{C})$ in the two groups of patients: those receiving linomide $(\square)$ and those receiving placebo (O). Data analysis is given in the Results section

Neither the presence or the titre of islet cell antibodies, GAD, IA2 or insulin autoantibodies, nor age, sex, duration of symptoms, degree of weight loss at diagnosis, nor the linomide posology per $\mathrm{kg}$ body weight were predictive of changes in insulin needs or $\mathrm{C}$ peptide in response to linomide. C peptide values at diagnosis showed some degree of prediction of values at 12 months $(\mathrm{y}=0.6 \times+0.22, r=0.36$, $p<0.02$ ).

At one year, 33 of 42 linomide treated and 20 of 21 control patients had insulin autoantibodies (NS). Insulin antibodies increased during the 12 month study in all patients $(p<0.001)$, but were lower in linomide treated patients at one year $(3.4 \pm 0.4 \%$ vs $13.4 \pm 1.8 \%(p<0.001)$. At one year, 25 of 42 linomide and 11 of 21 control patients had islet cell antibodies (NS). The titre of islet cell antibodies decreased significantly in both groups $(p<0.001)$. GAD antibodies were unchanged, and the reduction in IA-2 antibodies was significant only in the linomide treated group (from $40 \pm 7$ at diagnosis to $31 \pm 6$ at 1 year $(\mathrm{p}<0.01)$ (normal $<1.4)$.

We observed no correlation of any of the observed effects with linomide dosage per $\mathrm{kg}$ body weight.

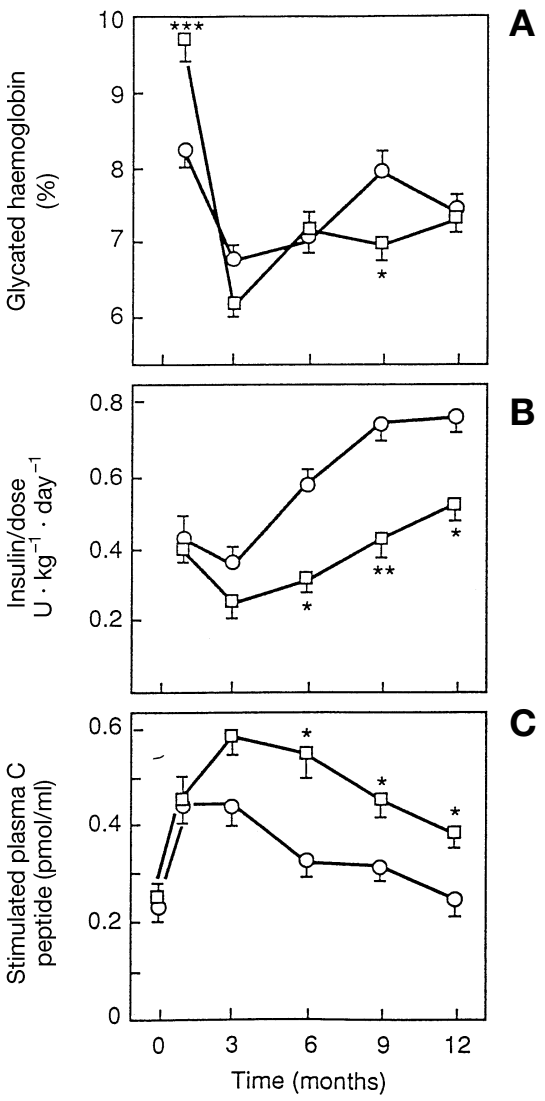

Fig. 2A-C. Evolution of glycated haemoglobin (A), insulin dose $(\mathbf{B})$ and glucagon-stimulated plasma $\mathrm{C}$ peptide $(\mathbf{C})$ in the 40 patients who still had detectable beta cell function at entry into the trial. Twenty five of them received linomide $(\square)$ and 15 placebo $(\bigcirc)$. Data analysis is given in the Results section

Subgroup with detectable beta cell function at diagnosis. The post hoc subgroup analysis in patients who still had detectable residual beta cell function at entry gave the following results. Among the linomide patients, 25 of $42(59 \%)$ had an initial stimulated C peptide value greater than $0.1 \mathrm{pmol} / \mathrm{ml}$, at entry compared with 15 of $21(72 \%)$ in the placebo group. These patients were selected to compose two subgroups. The linomide and placebo subgroups with detectable beta cell function at entry were comparable with respect to $\mathrm{C}$ peptide levels and other inclusion criteria (Table 1). However, the linomide group had a tendency for longer disease duration, greater weight loss and higher glycated haemoglobin.

In patients who still had detectable beta cell function at entry, linomide treatment was associated with lower glycated haemoglobin values than in the placebo group at 9 months $(6.9 \pm 0.2$ vs $8.1 \pm 0.6 \%$ $(p=0.02))$, then with comparable values at 12 months $(7.3 \pm 0.2$ vs $7.5 \pm 0.3 \%)$ (Fig. $2 \mathrm{~A})$.

The daily insulin doses of the 25 diabetic children with detectable beta cell function were 35-43\% smaller in the linomide than in the placebo group $-0.34 \pm 0.05$ vs $0.56 \pm 0.1 \mathrm{U} / \mathrm{kg}$ at 6 months $(p=$ 
Table 2. Comparison of secondary effects of linomide with the group receiving placebo

\begin{tabular}{lccc}
\hline Side effects & $\begin{array}{c}\text { Linomide } \\
(n=42)\end{array}$ & $\begin{array}{c}\text { Placebo } \\
(n=21)\end{array}$ & $p$ \\
\hline Anaemia (\%) & $19 / 42(45)$ & $2 / 21(10)$ & $<0.02$ \\
Mild thrombocytopenia (\%) & $10 / 42(24)$ & $2 / 21(10)$ & NS \\
Abdominal pain (\%) & $26 / 42(62)$ & $10 / 21(48)$ & NS \\
Thoracic pain (\%) & $4 / 42(10)$ & $2 / 21(10)$ & NS \\
Joint or back pain (\%) & $19 / 42(45)$ & $1 / 21(5)$ & $<0.01$ \\
Mild pain & $15 / 42$ & $0 / 21$ & \\
Moderate pain & $4 / 42$ & $1 / 21$ & \\
Myalgia (\%) & $16 / 42(38)$ & $11 / 21(53)$ & NS \\
Periorbital oedema (\%) & $11 / 42(26)$ & $4 / 21(19)$ & NS \\
\hline
\end{tabular}

$0.05), 0.43 \pm 0.06$ vs $0.75 \pm 0.1 \mathrm{U} / \mathrm{kg}$ at 9 months $(p=0.008)$ and $0.52 \pm 0.06$ vs $0.79 \pm 0.1 \mathrm{U} / \mathrm{kg}$ at 12 months $(p=0.03)$ (Fig. 2B).

Plasma $\mathrm{C}$ peptide concentrations were greater in the linomide subgroup than in the placebo-treated subgroup of patients $-0.54 \pm 0.07$ vs $0.34 \pm 0.04$ $\mathrm{pmol} / \mathrm{ml}$ at 6 months $(p<0.05), 0.45 \pm 0.04$ vs $0.31 \pm$ $0.05 \mathrm{pmol} / \mathrm{ml}$ at 9 months $(p=0.05), 0.38 \pm 0.04$ vs $0.25 \pm 0.05 \mathrm{pmol} / \mathrm{ml}$ at $12 \mathrm{months}(p<0.05)$. Patients treated with linomide had an increased ratio of stimulated serum $C$ peptide to glucose from 6 to 12 months of trial $(p<0.02)$. The only predictive parameter of the response to linomide was the plasma glucagon stimulated $\mathrm{C}$ peptide at entry in the trial.

Linomide toxicity. No serious adverse event occurred and blinding was maintained for all patients until the end of the study. No patient withdrew from the treatment because of an adverse event, and therefore all patients completed the one year study. No patient had any physical detectable signs of adverse effects at repeated clinical examination. Secondary effects of linomide are given in Table 2.

Mild anaemia (haemoglobin concentrations between 10 and $12 \mathrm{~g} / \mathrm{dl}$ ) was observed in $45 \%$ of linomide-treated patients. Erythrocytes were normochromic and normocytic, with an inappropriately low reticulocyte count. The mechanism of this pure erythrocyte anaemia is unknown. Mild transient thrombocytopenia (115 000-150 000 per $\mu \mathrm{l}$ ) occurred in $24 \%$ of patients. Six patients had both anaemia and thrombocytopenia. No bone marrow biopsy was performed since spontaneous recovery occurred within a few days of stopping treatment.

The granulocyte count was normal in all patients. Mild and transient (0.1-1 h) muscular discomfort was observed with a comparable frequency in both groups, as did non-specific headache and abdominal pain. One patient had marked myalgia for $6 \mathrm{~h}$. Joint discomfort was more frequent in the linomide group ( $45 \%$ vs $5 \%$ ). This was mild, not spontaneously mentioned by patients and was not associated with any clinical sign. No subject in the linomide group experienced nausea, vomiting or anorexia.

Body weight increased by $7.2 \pm 0.6 \mathrm{~kg} /$ year in the linomide group and $5.4 \pm 1.9 \mathrm{~kg} /$ year in the placebo group (NS). BMI increased by $0.8 \pm 0.2 \mathrm{kgm}^{2}$ and $1.4 \pm 0.4 \mathrm{~kg} / \mathrm{m}^{2}$ per year in the linomide and placebo groups respectively (NS). Caloric intakes were $1960 \pm 67 \mathrm{kcal} /$ day (linomide) and $1921 \pm 109 \mathrm{kcal} /$ day (placebo) between 6 and 12 months.

There were apparently no effects of treatment on physical activity since linomide-treated patients exercised $6 \pm 2$ vs $7 \pm 2 \mathrm{~h}$ per week in the placebo group. We observed no correlation of adverse effects with linomide dosage expressed per kg bodyweight.

\section{Discussion}

Type I diabetes in humans results from an immunemediated process of beta cell death, presumably through apoptotic mechanisms, as observed in murine models of the disease [24]. Recent data indicate that immunostimulation may confer protection from autoimmune diabetes in non-obese diabetic mice [25]. Linomide is an immunomodulating drug, which, if given at doses as low as $0.02 \mathrm{mg} / \mathrm{dl}$ of drinking water from the age of 5 weeks, prevents diabetes development in the non-obese diabetic mouse [14]. These results were duplicated by J. Timsit in our group. Linomide was still efficient when started later (at the age of 16 weeks) in prediabetic mice with extensive insulitis. Transfer experiments showed that linomide may work through the induction or activation of regulatory cells, having the capacity to down-regulate the immune response to beta cell antigens. The prevention of diabetes by linomide in the non-obese diabetic mouse model is associated with the abolition of the T cell proliferative defect [26] and with the upregulation of the $\mathrm{p} 21^{\text {ras }} \mathrm{T}$ cell signal transduction $[27$, 28].

Linomide (in a daily dose of $50-300 \mathrm{mg} / \mathrm{kg}$ ) showed protective effects in other experimental models of autoimmunity. It prevented neurological signs and lesions in experimental autoimmune encephalomyelitis, even when given 7 days after disease induction [29]. It prevents murine systemic lupus erythrematosus [30], autoimmune myasthenia gravis [31], virus-induced myocarditis [32], hepatitis induced by Fas antibodies [13], and glomerulonephritis [33]. It has paradoxical effects in experimental arthritis [34, 35].

Several mechanisms of action of linomide have been elucidated. One is the reduction of tumor necrosis factor $\alpha$ production in response to LPS [36], which possibly interferes with diabetes development in the non-obese diabetic mouse [37]. Another effect of linomide is the stimulation of natural killer cells [38, 39]. Linomide also inhibits the apoptotic decay of periph- 
eral T lymphocytes in response to superantigen stimulation, exogenous glucocorticoids or infection with vaccinia virus [40]. More recently, linomide was shown to inhibit ceramide-mediated apoptosis of hepatocytes [13].

Linomide is a quinoline-3-carboxamide derivative. It is well absorbed in humans after oral administration and has a mean plasma half life of $28-62 \mathrm{~h}$. The dose-response curve appears bell-shaped with, maximal immunostimulation at a daily dose of $0.2-0.4 \mathrm{mg} / \mathrm{kg}$ in man $[39,41]$, a dose 2-10 times higher than used in the present trial. In placebo-controlled trials, preliminary results at 6 months indicated that a dose of $2.5 \mathrm{mg} /$ day of linomide reduces active lesions in the relapsing remitting form of multiple sclerosis [42] and tends to inhibit the progression of its secondary progressive form [43].

Our observations show that a dose of $2.5 \mathrm{mg}$ of linomide daily has positive effects on residual insulin secretion and insulin needs in non-ketoacidotic Type I diabetes of recent onset. Although patients treated with linomide needed less insulin to achieve better control than the placebo group, it is worth noting that $\mathrm{C}$ peptide levels were only moderately greater. In both groups, $\mathrm{C}$ peptide showed a continuous fall beyond the first months of trial. Insulin doses correlated negatively with $\mathrm{C}$ peptide levels at each time point of the trial, as well as when the repeated measure analysis was used $(p<0.0001)$. This supports a causative effect of residual secretion upon reduction of insulin needs in linomide patients. The fact that C peptide concentrations were not significantly higher with linomide treatment than with placebo could be due to the large proportion of patients who had no detectable residual secretion at entry $-41 \%$ in the linomide group and $28 \%$ in the placebo group. This resulted in a wide dispersion of $\mathrm{C}$ peptide values. Because patients who lack $\mathrm{C}$ peptide are known to be poor responders to immunointervention $[3,8]$, and linomide protects residual beta cells from destruction in mice [14], we were particularly interested to evaluate the effects of the drug in patients who still had detectable beta cell function at entry. Ideally, the trial would have included only those patients, but for practical reasons, we could not use C peptide measurements in the inclusion criteria. Our only way of determining linomide effects on residual beta cell function in this study was therefore to perform post hoc analysis in subgroups. This analysis showed a consistent $45-59 \%$ increase in C peptide concentrations in the linomide group between months 6 and 12 of the trial. Clinically accessible determinants of insulin sensitivity - such as physical activity, food intake or body weight changes - were comparable in both groups and did not seem to be influenced by linomide. Linomide treated patients even showed a slight tendency to gain more weight and BMI.
The mechanisms of beta cell dysfunction and destruction in human Type I diabetes remain unknown. It is possible, although entirely speculative, that linomide interferes with the autoimmune attack on beta cells through non-specific immunomodulatory effects or with processes leading to secretory dysfunction and death of beta cells. Blockade of apoptosis by linomide was shown in hepatocytes of mice exposed to Fas-antibody induced hepatitis [13].

In our study, the secondary effects of linomide were very mild, consisting mostly of anaemia and slight symptoms of arthralgia, and there were no clinical signs [39, 42-44]. However, 13 cases of pericardial effusion have been reported among 754 patients with multiple sclerosis or leukaemia [43]. Although we did not observe this complication of linomide in our study subjects, the relatively small size of the cohort does not allow a firm statement about the innocuity of the drug.

Our results are to be considered preliminary, since only a unique fixed minimal dose of linomide was tested in a small cohort of new-onset juvenile diabetics, a large number of whom already had complete beta cell destruction. The optimal dose and regimen remain to be determined. In this respect, an interesting target could be the adult form of Type I diabetes, because it has a longer evolution period between the immune attack and the definitive disappearance of beta cell mass. However, because of the secondary effects reported in adults with multiple sclerosis or leukaemia, these trials cannot take place in diabetics, particularly children, unless linomide safety is re-established by further studies.

Acknowledgements. This study would not have been performed without the seminal observation of Shimon Slavin in the non-obese diabetic mice.

This trial could not have been undertaken without our colleages who referred their patients: M.C. Wieliczko MD, Rouen; S. Treppoz MD, A. Servan MD, Lyon; B. Gendrault MD, Nancy; O. Richard MD, C. Berger MD, Saint Etienne; J. Bouquier MD, A. Lienhardt MD, C. Laroche MD, Limoges; F. Despert MD, Tours; D. Asensi MD, B. Rétali MD, Pontoise; F. Huet MD, Dijon, J.B. Cotton MD, Valence; H. Thibault MD, Colombes; J.M. Limal MD, C. Radet MD, Angers; S. Pradines MD, Grenoble; M. Odièvre MD, Clamart; A. Avignon MD, Argentan; C. Thivolet MD, Lyon; J.F. Féron MD, Orléans; M. F. Pillot MD, Montceau Les Mines; D. Lambrey MD, Beauvais; C. Vervel MD, Compiègne; Y. LeBouar MD, Autun; C. Méchain MD, Evry. We thank them for all their confidence and close collaboration.

We are indebted to B. Aboumrad and M. J. Pezeron for dedicated care of the patients and to N. Frament for daily organisation. We thank C. Dos Santos and C. Lotton for measurement of autoantibodies. D. Gruffaz (Pharmacia, France) was of major help for continuous data collection. We thank Muriel Delacroix for excellent secretarial assistance. 


\section{References}

1. Stiller CR, Dupré J, Gent M et al (1984) Effects of cyclosporine immunosuppression in insulin-dependent diabetes mellitus of recent onset. Science 223: 1362-1367

2. Assan R, Feutren G, Debray-Sachs M et al (1985) Metabolic and immunological effects of cyclosporin in recently diagnosed type I diabetes mellitus. Lancet 1: 67-71

3. Bougnères PF, Carel JC, Castanl L et al (1988) Factors associated with early remission of type I diabetes in children treated with cyclosporine. N Engl J Med 318: 663-670

4. Bougnères PF, Landais $P$, Boison C et al (1990) Limited duration of the remission of insulin dependency in children with recent overt type I diabetes treated with low dose cyclosporin. Diabetes 39: 1264-1272

5. De Filippo G, Carel JC, Boitard C, Bougnères PF (1996) Longterm results of early cyclosporin therapy in juvenile IDDM. Diabetes 45: 101-104

6. Canadian-European Randomized Control Trial Group (1988) Cyclosporin-induced remission of IDDM after early intervention: association of $1 \mathrm{yr}$ of cyclosporin treatment with enhanced insulin secretion. Diabetes 37: 1574-1582

7. Feutren G, Mihatsch MJ (1992) Risk factors for cyclosporin-induced nephropathy in patients with autoimmune diseases. N Engl J Med 326: 1664-1670

8. Silverstein J, MacLaren N, Riley W, Spillar R, Radjenovic D, Johnson $S$ (1988) Immunosuppression with azathioprine and prednisone in resent-onset insulin-dependent diabetes mellitus. N Engl J Med 319: 99-604

9. Harrison LC, Coleman PG, Dean B, Baxter R, Martin FIR (1985) Increase of remission rate in newly diagnosed type I diabetic subjects treated with azathioprine. Diabetes 34: 1306-1308

10. Eisenbarth GS, Verge CF, Allen H, Rewers MJ (1993) The design of trials for prevention of IDDM. Diabetes 42: 941-947

11. Pozzili P, MacLaren NK (1993) Immunotherapy at clinical diagnosis of insulin-dependent diabetes. An approach still worth considering. Trends Endocr Metab 4: 101-105

12. Karussis DM, Lehmann D, Slavin S et al (1993) Successful treatment of chronic-relapsing experimental autoimmune encephalomyelitis by the synthetic immunomodulator linomide (quinoline-3carboxamide). Proc Natl Acad Sci USA 90: 6400-6404

13. Redondo C, Flores I, Gonzales A et al (1996) Linomide prevents the lethal effect of anti-Fas antibody and reduces Fas-mediated ceramide production in mouse hepatocytes. J Clin Invest 98: 1245-1252

14. Gross DJ, Sidi H, Weiss L, Kalland T, Rosenmann E, Slavin S (1994) Prevention of diabetes mellitus in non-obese diabetic mice by linomide, a novel immunomudulating drug. Diabetologia 37: 1195-1201

15. Karjalainen J, Samela P, Ilonen J, Surcel HM, Knip M (1989) A comparison of childhood and adult type I diabetes mellitus. N Engl J Med 320: 881-886

16. Caillat-Zucman S, Garchon HJ, Timsit J et al (1992) Age-dependent HLA genetic heterogeneity of type I insulin-dependent diabetes mellitus. J Clin Invest 90: 2242-2250

17. National Diabetes Data Group (1979) Classification and diagnosis of diabetes mellitus and other categories of glucose intolerance. $\mathrm{Di}$ abetes 328: 1039-1057

18. Lehto M, Tuomi T, Mahtani MM et al (1997) Characterization of the MODY3 phenotype. J Clin Invest 99: 582-591

19. Bougnères PF, Landais $P$, Mairesse et al (1993) Improvement of diabetic control and acceptability of a three-injection insulin regimen in diabetic adolescents. Diabetes Care 16: 94-102

20. Krisher JP, Schatz D, Riley WJ et al (1993) Insulin and islet cell autoantibodies as time-dependent covariates in the development of insulin-dependent diabetes: a prospective study in relatives. J Clin Endocrinol Metab 77: 743-749

21. Petersen J, Hejnaes KR, Moody A et al (1994) Detection of GAD 65 antibodies in diabetes and other autoimmune diseases using a simple radioligand assay. Diabetes 43: 459-567

22. Kawasaki E, Yu L, Gianani R, Verge CF, Babu S, Bonifacio E, Eisenbarth GS (1997) Evaluation of islet cell antigen (ICA) 512/IA 2 autoantibody using overlapping ICA 512/IA-2 constructs. J Clin Endocrinol Metab 82: 375-380

23. Castano L, Boitard C, Bougnères PF (1988) Cyclosporin A suppresses insulin autoantibodies and heterologous insulin antibodies in type I diabetic children. Diabetes 37: 1049-1052
24. Kurrer MO, Pakala SV, Hanson HL, Katz JD (1997) $\beta$ cell apoptosis in T cell-mediated autoimmune diabetes. Proc Natl Acad Sci 94: 213-218

25. Rabinovitch A (1994) Immunoregulatory and cytokine imbalances in the pathogenesis of IDDM: therapeutic intervention by immunostimulation? Diabetes 43: 613

26. Larson ET (1987) The mechanisms of action of the new immunomodulator LS2616 on T cell responses. Int J Immunopharmacol 9: 425

27. Rapoport MJ, Weiss L, Mor A, Bistritzer T, Ramot Y, Slavin S (1996) Prevention of autoimmune diabetes by linomide in nonobese diabetic (NOD) mice is associated with up-regulation of the

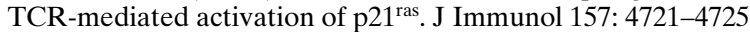

28. Raoport MJ, Lazarus AH, Jaramillo A, Speck E, Delovitch TL (1993) Thymic T cell anergy in autoimmune nonobese diabetic mice is mediated by deficient $\mathrm{T}$ cell receptor regulation of the pathway of $\mathrm{p} 21^{\text {ras }}$ activation. J Exp Med 177: 1221

29. Karussis DM, Lehmann D, Slavin S et al (1993) Inhibition of acute, experimental autoimmune encephalomyelitis by the synthetic immunomodulator linomide. Ann Neurol 34: 654-660

30. Tarkowski A, Gunnarsson K, Stälhandske T (1986) Effects of LS 2616 administration upon the autoimmune disease of (NZB/ NZW) F1 hybrid mice. Immunology 59: 589-594

31. Karussis D, Lehmann D, Brenner T et al (1994) Immunomodulation of experimental autoimmune myasthenia gravis with linomide. J Neuroimmunol 55: 187-193

32. Ilbäck N, Fohlman J, Slornch S, Friman G (1989) Effects of the immunomodulator LS 2616 on lymphocyte subpopulations in murine Coxsackie virus B3 myocarditis. J Immunol 142: 3225-3228

33. Hortelano S, Diaz-Guerra MJM, Gonzalez-Garcia A et al (1997) Linomide administration to mice attentuates the induction of nitric oxide synthase elicited by lipopolysaccharide-activated macrophages and prevents nephritis in MRL/Mp-Ipr/Ipr Mice. J Immunol 158: $1402-1408$

34. Kleinau S, Larsson P, Björk J, Holmdahl R, Klareskog L (1989) Linomide, a new immunomodulatory drug, shows different effects on homologous versus heterologous collagen-induced arthritis in rats. Clin Exp Immunol 78: 138-142

35. Björk J, Kleinau S (1989) Paradoxical effects of LS-2616 (linomide) treatment in the type II collagen arthritis model in mice. Agents Actions 27: 319-321

36. Gonzalo JA, Gonzalez-Garcia A, Kalland T, Hedlund G, Martinez AC, Kroemer G (1993) Linomide, a novel immunomodulator that inhibits death in four different models of septic shock. Eur J Immunol 23: 2372-2374

37. Jacob CO, Aiso S, Michie SA, McDevitt HO, Acha-Orbea H (1990) Prevention of diabetes in nonobese diabetic mice by tumor necrosis factor (TNF): similarities between TFN-alpha and interleukin 1. Proc Natl Acad Sci USA 87: 968-972

38. Kalland T, Alm G, Stalhandske T (1985) Augmentation of mouse natural killer activity by LS-2616, a new immunomodulator. J Immunol 134: 3956-3961

39. Bengtsson M, Simonsson B, Carlsson K et al (1992) Stimulation of NK cell, T cell, and monocyte functions by the novel immunomodulator linomide after autologous bone marrow transplantation. Transplantation 53: 882-888

40. Gonzalo JA, Gonzalez-Garcia A, Kalland T, Hedlung G, Martinez C, Kroemer G (1994) Linomide inhibits programmed cell death of peripheral T cells in vivo. Eur J Immunol 24: 48-52

41. Deeg HJ, Henslee-Downey PJ (1990) Management of acute graftversus-host disease. Bone Marrow Transplant 6: 1

42. Andersen O, Lycke J, Tollesson PO et al (1996) Linomide reduces the rate of active lesions in relapsing-remitting multiple sclerosis. Neurology 47: 895-900

43. Karussis DM, Meiner Z, Lehmann D et al (1996) Treatment of secondary progressive multiple sclerosis with the immunomodulator linomide: a double-blind, placebo-controlled pilot study with monthly magnetic resonance imaging evaluation. Neurology 47: 341-346

44. Bergh J, Totterman TH, Termander B et al (1989) Marked stimulation of the immune system by linomide in cancer patients-I study. Presented at the 5th Ecco Meeting, London, Sept 3-7 